\title{
'LEGAL IDENTITY FOR ALL’ AND STATELESSNESS: OPPORTUNITY AND THREAT AT THE JUNCTION OF PUBLIC AND PRIVATE INTERNATIONAL LAW
}

\author{
BRONWEN MANBY*
}

\begin{abstract}
This article considers the impact of Target 16.9 of the Sustainable Development Goals ('SDGs'), 'to provide legal identity for all, including birth registration' on the objective of eradicating statelessness. This SDG Target has given a significant boost to initiatives for the strengthening of civil registration and identification systems, supported by the United Nations and World Bank. Yet its impact on the resolution of statelessness is not clear, because of the immense complexity of the definition of 'legal identity'. Proposed definitions, adopted after the target was established, fail to take on board the challenges involved in cross-border recognition of civil status documents and the determination of nationality of a child for parents who hold no documents. The article concludes that SDG Target 16.9 is both an opportunity and a threat. If the objective of providing universal 'legal identity' is to have a positive impact for stateless persons there is a need for new engagement with the regulation of civil status in private international law, and new insistence in public international law on legal frameworks that facilitate recognition and registration of the different elements of a person's identity, including nationality, even and especially where they are officially in doubt. Short cuts in this process risk long delays.
\end{abstract}

\section{TABLE OF CONTENTS}

I The Sustainable Development Goals and Legal Identity ................................... 248

II Legal Identity and Birth Registration in International Law ................................ 250

III Civil Registration and Conflicts of Law ........................................................... 254

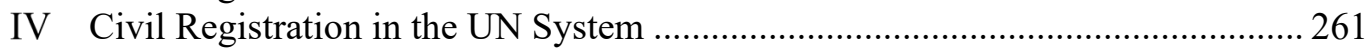

V Legal Identity, Digital Identity and Development ............................................. 262

VI The Dangers of Short Cuts: Population Registration and the Creation of

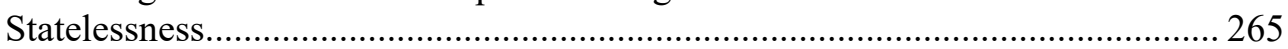

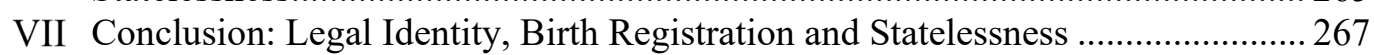

\section{The Sustainable DeVelopment Goals and Legal Identity}

In September 2015, the United Nations General Assembly adopted the Sustainable Development Goals ('SDGs'), an ambitious set of objectives for international development to replace and expand upon the 15-year-old Millennium Development Goals adopted in 2000. Goal 16 is one of the broadest: 'Promote peaceful and inclusive societies for sustainable development, provide access to justice for all and build effective, accountable and inclusive institutions at all levels'. Each Goal has a set of more detailed targets: Target 16.9 requires that

* Senior Policy Fellow and Guest Teacher MSc Human Rights, London School of Economics and Political Science. Thanks to Jaap van der Straaten, Kirsten di Martino, Alenka Prvinšek Persoglio, Christoph Sperfeldt, René de Groot, David de Groot and Aashish Yadav for comments on a draft of this paper, as well as the two anonymous reviewers. This article is twinned with another in which the broader implications of the 'legal identity' target are discussed: Bronwen Manby, 'The Sustainable Development Goals and "Legal Identity for All": "First, Do No Harm"” (2021) World Development (forthcoming). 
states should, by 2030, 'provide legal identity for all, including birth registration' ${ }^{1}$ The indicator adopted to measure progress towards Target 16.9 was the percentage of children under five whose births have been registered, a statistic already widely available. $^{2}$

One year earlier, the United Nations High Commissioner for Refugees ('UNHCR') had launched a ten-year campaign to end statelessness by 2024, the \#IBelong campaign, including a ten-point global action plan, with universal birth registration as Action 7 . While birth registration in itself does not confer nationality, and is usually not legally proof of nationality, the official record of the place and date of birth and identity of the parents of the child provides critical evidence of the facts that enable the child to assert the right to nationality in one or more states. ${ }^{3}$ In principle, SDG Target 16.9 should provide a significant boost to the achievement of UNHCR's campaign, especially the ambition to end statelessness at birth.

Yet it is notable that the SDG target endorsed by states was for a less specific and less demanding target — legal identity rather than nationality for all — and set a longer time frame than the UNHCR campaign. On the one hand, the meaning of 'legal identity' was not clear; on the other, a person may have a document that is official proof of identity and yet still be stateless. The SDG target also does not have any equivalent to Action 8 in the \#IBelong campaign, calling on states to issue nationality documentation to those with entitlement to it.

At past the halfway point in the UNHCR campaign, now is a good moment to evaluate the contribution of the SDG target to its realisation, and whether the drive for 'legal identity' is a threat or an opportunity for the stateless. From the outset, there were concerns that the legal identity target in the SDGs could be a distraction from the campaign to eradicate statelessness, or even prove to be damaging, if underlying laws were not reformed before new official identification initiatives were rolled out. ${ }^{4}$ There is also a long history of scholarship about the double nature of identification and registration systems: as tools to build state capacity and social welfare systems, and enable those registered to assert their rights, as the SDG

1 'Sustainable Development Goal 16', United Nations Department of Economic and Social Affairs Sustainable Development Knowledge Platform (Web Page, 2015) $<$ https://sustainabledevelopment.un.org/sdg16>.

2 SDG indicators available at: Sustainable Development Goal Indicators Website (Web Page) $<$ http://unstats.un.org/sdgs/>. Birth registration data is collected through UNICEF's Multiple Indicator Cluster Surveys and the USAID-funded Demographic and Health Surveys. Coverage of children under one year old was also considered in Birth Registration for Every Child by 2030: Are We on Track? (Report, UNICEF December 2019) $<$ https://data.unicef.org/resources/birth-registration-for-every-child-by-2030/>.

3 Guidelines on Statelessness No 4: Ensuring Every Child's Right to Acquire a Nationality through Articles 1-4 of the 1961 Convention on the Reduction of Statelessness (Guidelines, UNHCR 21 December 2012); I Am Here, I Belong: The Urgent Need to End Childhood Statelessness (Report, UNHCR November 2015); Good Practices Paper Action 7: Ensuring Birth Registration for the Prevention of Statelessness (Good Practices Paper, UNHCR November 2017). See also the UNHCR and UNICEF-led coalition on every child's right to a nationality: IBELONG: Coalition on Every Child's Right to a Nationality (Web Page) $<$ https://www.unhcr.org/ibelong/unicef-unhcr-coalition-child-right-nationality/>.

4 Bronwen Manby, “"Legal Identity for All” and Childhood Statelessness' in Laura van Waas and Amal de Chickera (eds), The World's Stateless: Children (Report, Institute on $\begin{array}{llll}\text { Statelessness and Inclusion } & \text { January }\end{array}$ $<$ http://children.worldsstateless.org/3/childhood-statelessness-and-the-sustainabledevelopment-agenda/legal-identity-for-all-and-childhood-statelessness.html $>$. 
target intends; but also as instruments of exclusion, surveillance and control. ${ }^{5}$ Moreover, the process of sorting individuals into different nationalities is, by its nature, discriminatory and not necessarily empowering. ${ }^{6}$ But even if we accept the assumption that recognition and registration of a person's legal identity by the state is 'the crucial primary instrument for realising entitlements', ${ }^{7}$ and that recognition or acquisition of nationality is always a good, what has become most apparent in six years is the immense complexity of an assessment of the SDG commitment to 'provide legal identity' in relation to the resolution of statelessness.

The following Parts set out the existing legal framework for 'identity' and birth registration in international law; followed by a discussion of the complexities of the recognition of civil registration documents across borders; the contribution of the UN system to the strengthening of civil registration systems; the interpretation of the 'legal identity' target by the development community; and finally the likely interaction between 'legal identity' and the effort to end statelessness. The article concludes that the combined efforts of private and public international law are needed to overcome the very substantial risk that short cuts will create long delays for stateless persons, and to ensure that the target has a positive impact on the prevention and reduction of statelessness. SDG Target 16.9 is both an opportunity and a threat for those who are most marginalised within current systems for official recognition of legal identity.

\section{LEGAL IDENTITY AND BIRTH REGISTRATION IN INTERNATIONAL LAW}

The difficulty of understanding the potential impact of SDG Target 16.9 starts from the fact that 'legal identity' is not a term that had any pre-existing definition in international law. The indicator adopted to measure progress, the percentage of children under five whose birth has been registered, leaves significant uncertainty on what it would take to know that the target had been reached; 8 thus, 'there is no simple answer to the measurement question'. ${ }^{9}$ This is most obviously true in relation to any person over five years old; but also for birth registration itself, both the technical criteria for measuring coverage, and the elements of identity that should be recorded within the birth register.

5 Collected volumes of the past two decades review this history in comparative perspective: see Jane Caplan and John Torpey (eds), Documenting Individual Identity: The Development of State Practices in the Modern World (Princeton University Press 2001); Colin J Bennett and David Lyon (eds), Playing the Identity Card: Surveillance, Security and Identification in Global Perspective (Routledge 2008); Keith Breckenridge and Simon Szreter (eds), Registration and Recognition: Documenting the Person in World History (Oxford University Press 2012); Ilsen About, James Brown and Gayle Lonergan (eds), Identification and Registration Practices in Transnational Perspective: People, Papers and Practices (Palgrave Macmillan 2013).

6 Dimitry Kochenov, Citizenship (MIT Press 2019); Dimitry Kochenov and Justin Lindeboom (eds), Kälin and Kochenov's Quality of Nationality Index: An Objective Ranking of the Nationalities of the World (Hart Publishing 2020).

7 Simon Szreter and Keith Breckenridge, 'Editors' Introduction: Recognition and Registration: The Infrastructure of Personhood in World History' in Breckenridge and Szreter (n 5) 1, 12.

8 Jaap van der Straaten, 'Legal Identity for All by 2030: How Will We Know?' (Position Paper, Civil Registration Centre for Development-CRC4D 2015) $<$ https:/www.crc4d.com/downloads/2015-10-legal-identity-for-all-by-2030-how-will-weknow-position-paper.pdf $>$.

9 Alan Gelb and Anna Diofasi Metz, Identification Revolution: Can Digital ID Be Harnessed for Development? (Center for Global Development 2018) 36. 
A range of international human rights standards, starting from art 6 of the Universal Declaration of Human Rights ('UDHR'), ${ }^{10}$ reinforced by art 16 of the International Covenant on Civil and Political Rights ('ICCPR'), ${ }^{11}$ establish that every person has the right to recognition everywhere as a person before the law. Although there has been little clarification on detailed content of this formulation, it 'expresses the right and the capacity of each human being to be the holder of rights and obligations under the law', ${ }^{12}$ enabling a person to assert rights, to enforce contracts or to defend a case in court. ${ }^{13}$ This right is not dependent on existence in any register nor on holding official identification papers; it is already attributed by international law. Indeed, neither the drafters of the UDHR nor those of the 1959 Declaration of the Rights of the Child considered it necessary to include the right to birth registration as a free-standing right — though both proclaimed the right to a name and nationality. ${ }^{14}$

It was only with the adoption of the ICCPR in 1966 that a right to birth registration was enshrined, based on concern about the rights of refugee and displaced children, and those born out of wedlock — and freed by this date from the colonial states' hesitancy about the implications of universal birth registration for the rights of colonised populations. ${ }^{15}$ Article 24 of the ICCPR provides for every child to have the right to a name, to be registered immediately after birth and to acquire a nationality. The same commitments are reinforced (with variations in wording) by art 7 of the Convention on the Rights of the Child (' $\left.C R C^{\prime}\right)^{16}$ — adopted in 1989 and by which every state in the world except for the United States has agreed to be bound - and art 29 of the 1990 International Convention on the Protection of the Rights of All Migrant Workers and Members of Their Families. ${ }^{17}$

Article 8 of the $C R C$ also introduced the overarching concept of 'identity' to international law, establishing the child's right 'to preserve his or her identity, including nationality, name and family relations as recognized by law'. ${ }^{18}$ The product of advocacy efforts by the newly democratic Argentinian government in the wake of forced adoptions during the military dictatorship, and building on existing Latin American frameworks of recognition for child rights, ${ }^{19}$ art 8 places

10 Universal Declaration of Human Rights, GA Res 217A (III), UN GAOR, $3^{\text {rd }}$ sess, 183rd plen mtg, UN Doc A/810 (10 December 1948).

11 International Covenant on Civil and Political Rights, opened for signature 16 December 1966, 999 UNTS 171 (entered into force 23 March 1976).

12 Working Group on Enforced or Involuntary Disappearances, General Comment on the Right to Recognition as a Person before the Law in the Context of Enforced Disappearances, UN Doc A/HRC/19/58/Rev.1 (2 March 2012).

13 Sarah Joseph and Melissa Castan, The International Covenant on Civil and Political Rights: Cases, Materials, and Commentary ( $3^{\text {rd }}$ edn, Oxford University Press 2013) 329-39.

14 Declaration on the Rights of the Child, GA Res 1386 (XIV), UN GAOR, $14^{\text {th }}$ sess, $841^{\text {st }}$ plen mtg, Agenda Item 64, Supp No 16, UN Doc A/4354 (20 November 1959) principle 3.

15 Dominique Marshall, 'Birth Registration and the Promotion of Children's Rights in the Interwar Years' in Breckenridge and Szreter (n 5) 449, 464-70.

16 Convention on the Rights of the Child, opened for signature 20 November 1989, 1577 UNTS 3 (entered into force 2 September 1990) ('CRC').

17 International Convention on the Protection of the Rights of All Migrant Workers and Members of Their Families, opened for signature 18 December 1990, 2220 UNTS 3 (entered into force 1 July 2003).

18 CRC (n 16) art 8.

19 Rita Arditti, Searching for Life: The Grandmothers of the Plaza de Mayo and the Disappeared Children of Argentina (University of California Press 1999); Anne-Emmanuelle Birn, 'Uruguay's Child Rights Approach to Health: What Role for Civil Registration?' in Breckenridge and Szreter (n 5) 415. 
an obligation on states to re-establish identity if 'a child is illegally deprived of some or all of the elements of his or her identity'. ${ }^{20}$ The $C R C$ establishes the content of 'identity' through an open rather than closed list, allowing for other elements to be included beyond name, nationality, and family relations, as appropriate in the context. ${ }^{21}$ In essence, it creates the obligation for child protection systems to move beyond welfare and take seriously the importance of establishing the legal connections of a child to his or her family, broadly defined, in the eyes of the government. This includes the case of abandoned or separated children whose biological parents should be sought, and independent legal recognition established if this is not possible.

The right to recognition as a person before the law is thus, in international law, not dependent on existence in any register nor on holding official identification papers. Similarly, the right to preserve an identity in the $C R C$ is not formally dependent on birth registration: a child's nationality should be recognised, for example, if the criteria are fulfilled, even in the absence of an existing birth certificate or other document confirming that fact. Family relations should be recognised by the state even if never previously officially recorded. The documents are declaratory, not constitutive.

However, it has for a long time also been clear that without official recognition that a person exists, and has rights set out in national law, the human rights protections established in international law may be worth little: 'nonsense on stilts', as famously denigrated by Jeremy Bentham. ${ }^{22}$ The importance of birth registration as an essential safeguard for other rights is now everywhere emphasised by the UN system. ${ }^{23}$ Universal birth registration is a central objective of UNICEF's child protection work, aiming to overcome both weaknesses in state capacity and deliberate patterns of discrimination. ${ }^{24}$ Treaty bodies have repeatedly highlighted the importance of both registration and the issue of a birth certificate: in combating trafficking of children, and providing proof of age for the purposes of criminal justice, immigration control, and marriage. ${ }^{25}$

$20 \quad C R C$ (n 18) art 8.

21 See generally Jaap E Doek, Article 8: The Right to Preservation of Identity; Article 9: The Right Not to Be Separated from His or Her Parents, ed André Alen et al (Martinus Nijhoff Publishers 2006).

22 Jeremy Bentham, Rights, Representation, and Reform: Nonsense upon Stilts and Other Writings on the French Revolution, ed Philip Schofield, Catherine Pease-Watkin and Cyprian Blamires (Oxford University Press 2002).

23 Human Rights Council, Birth Registration and the Right of Everyone to Recognition Everywhere as a Person before the Law: Report of the Office of the United Nations High Commissioner for Human Rights, UN Doc A/HRC/27/22 (17 June 2014); see also Human Rights Council, Birth Registration and the Right of Everyone to Recognition Everywhere as a Person Before the Law, UN Doc A/HRC/RES/19/9 (3 April 2012); Human Rights Council, Birth Registration and the Right of Everyone to Recognition Everywhere as a Person before the Law, UN Doc A/HRC/RES/22/7 (9 April 2013).

24 Every Child's Birth Right: Inequities and Trends in Birth Registration (Report, UNICEF 2013); A Passport to Protection: A Guide to Birth Registration Programming (Handbook, UNICEF December 2013).

25 Committee on the Rights of the Child, General Comment No 21: Children in Street Situations, UN Doc CRC/C/GC/21 (21 June 2017); Committee on the Protection of the Rights of All Migrant Workers and Members of Their Families and Committee on the Rights of the Child, Joint General Comment No 4 and No 23: State Obligations Regarding the Human Rights of Children in the Context of International Migration in Countries of Origin, Transit, Destination and Return, UN Doc CMW/C/GC/4-CRC/C/GC/23 (16 November 2017); Committee on the Protection of the Rights of All Migrant Workers and Members of Their Families, General Comment No 2: The Rights of Migrant Workers in an Irregular Situation and Members of Their Families, UN Doc CMW/C/GC/2 (28 August 2013). 
The importance of registration and documentation have also been emphasised at regional level. In its leading decision concerning the Dominican Republic, the Inter-American Court of Human Rights ruled that the two complainants had been placed 'in fear of being expelled by the State of which they were nationals and separated from their families owing to the absence of a birth certificate', and found the Dominican Republic in violation of multiple articles of the American Convention on Human Rights, including the right to nationality, to recognition as a person before the law, and to the protection of children and the family. ${ }^{26}$ The African Commission on Human and Peoples Rights has heard repeated cases relating to the refusal to recognise a person as a national who had previously held identity documents confirming nationality, finding violations of numerous articles of the African Charter on Human and Peoples' Rights. ${ }^{27}$ The African Committee of Experts on the Rights and Welfare of the Child, responsible for the African Charter on the Rights and Welfare of the Child, has emphasised the importance of birth registration and the right to a nationality in cases against Kenya and Sudan, and in a comprehensive General Comment. ${ }^{28}$ The African Court on Human and Peoples' Rights has confirmed the Commission's view that the right to a nationality is implied by the protection for dignity and legal status in art 5 of the African Charter on Human and Peoples' Rights, which is violated by the refusal to renew or issue documents. ${ }^{29}$ The European Court of Human Rights has also ruled, in a case concerning stateless individuals in Slovenia, that the 'erasure' of their registration as residents and the destruction of their identity documents had 'deprived the applicants of their legal status' and accordingly violated their right to private and family life. 30

International law is clear, therefore, that the right to 'identity' encompasses not only birth registration but also registration of other elements of identity, including nationality - and, in some contexts, other forms of legal status in a country. However, the current international legal framework places only limited restrictions on the discretion of states to determine who are their nationals. Historically, the concern was largely the imposition of nationality without a person's (implied) consent. ${ }^{31}$ Today, attention has shifted to the avoidance of

26 Case of the Girls Yean and Bosico v Dominican Republic (Judgment) (Inter-American Court of Human Rights, Series C 130, 8 September 2005) 65-66 [173].

27 See Bronwen Manby, Citizenship Law in Africa: A Comparative Study ( ${ }^{\text {rd }}$ edn, Open Society Foundations 2016) 33-36.

28 African Committee of Experts on the Rights and Welfare of the Child, General Comment No 2: Article 6 of the African Charter on the Rights and Welfare of the Child - 'Right to a Name, Birth Registration and a Nationality', Doc No ACERWC/ GC/ 02 (7-16 April 2014); African Committee of Experts on the Rights and Welfare of the Child, Decision on the Communication Submitted by the Institute for Human Rights and Development in Africa and Open Society Justice Initiative on behalf of Children of Nubian Descent in Kenya v Kenya, Doc No 002/Com/002/2009 (22 March 2011); African Committee of Experts on the Rights and Welfare of the Child, Decision on the Communication Submitted by the African Centre of Justice and Peace Studies (ACJPS) and People's Legal Aid Centre (PLACE) v Republic of Sudan, Doc No 005/Com/001/2015 (31 May 2018).

29 Anudo Ochieng Anudo v United Republic of Tanzania (African Court on Human and Peoples' Rights, App No 012/2015, 22 March 2018); Robert John Penessis v United Republic of Tanzania (African Court on Human and Peoples' Rights, App No 013/2015, 28 November 2019).

30 Kurić v Slovenia [2012] IV Eur Court HR 1, [356]; see also Smirnova v Russia [2003] IX Eur Court HR 241, 250 [96].

31 Paul Weis, Nationality and Statelessness in International Law (2 $2^{\text {nd }}$ edn, Brill 1979) 95-115. See also Bronwen Manby, 'Nationality and Statelessness among Persons of Western Saharan Origin' (2020) 34(1) Journal of Immigration, Asylum and Nationality Law 9. 
statelessness and discrimination. The most important specific obligation placed on states for the reduction of statelessness is to grant nationality to a child born in the territory who is otherwise stateless; that is, who does not acquire a nationality from one of the parents - at least for those states that are parties to the American Convention on Human Rights, the African Charter on the Rights and Welfare of the Child, or the UN Convention on the Reduction of Statelessness. ${ }^{32}$ Discrimination based on gender in transmission of nationality to children and spouses is prohibited by the Convention on the Elimination of All Forms of Discrimination against Women. ${ }^{33}$ Discrimination based on racial, ethnic or religious grounds is more difficult to prohibit, given the nature of nationality based on descent, although it is increasingly frowned upon. ${ }^{34}$ It is here that many problems of statelessness originate. ${ }^{35}$

Even for those states that have the minimum protections against statelessness, the challenge is to prove that a child is 'otherwise stateless': how do you prove a negative? What documents must the parents produce (or prove that they cannot obtain), for their child to acquire their nationality or the nationality of the state of birth? The devil in the detail of the procedures for registration of legal identity shows its horns.

\section{Civil REgistration AND CONFLICTS OF LAW}

There is extensive international guidance on the implementation of birth registration, within a broader framework of civil registration. ${ }^{36}$ Yet neither the SDG target on legal identity nor the UNHCR Global Action Plan to End

32 For a general outline of the international law obligations, see, eg, Serena Forlati, 'Nationality as a Human Right' in Alessandra Annoni and Serena Forlati (eds), The Changing Role of Nationality in International Law (Routledge 2013); Alice Edwards, 'The Meaning of Nationality in International Law in an Era of Human Rights: Procedural and Substantive Aspects' in Alice Edwards and Laura van Waas (eds), Nationality and Statelessness under International Law (Cambridge University Press 2014); Peter J Spiro, 'Citizenship, Nationality, and Statelessness' in Vincent Chetail and Céline Bauloz (eds), Research Handbook on International Law and Migration (Edward Elgar Publishing 2014).

33 Convention on the Elimination of All Forms of Discrimination against Women, opened for signature 18 December 1979, 1249 UNTS 13 (entered into force 3 September 1981) art 9 ('CEDAW').

34 Peter J Spiro, ‘A New International Law of Citizenship’ (2011) 105(4) American Journal of International Law 694; Committee on the Elimination of Racial Discrimination, General Recommendation XXX on Discrimination against Non-Citizens, UN Doc A/59/18 (2-20 August 2004) 93 [469].

35 This Is Our Home: Stateless Minorities and Their Search for Citizenship (Report, UNHCR November 2017) <https://www.unhcr.org/ibelong/stateless-minorities/>; Fernand de Varennes, Report of the Special Rapporteur on Minority Issues: Statelessness: A Minority Issue, UN Doc A/73/205 (20 July 2018); E Tendayi Achiume, Report of the Special Rapporteur on Contemporary Forms of Racism, Racial Discrimination, Xenophobia and Related Intolerance: Racial Discrimination in the Context of Citizenship, Nationality and Immigration Status, UN Doc A/HRC/38/52 (25 April 2018).

36 Most authoritatively, Principles and Recommendations for a Vital Statistics System (Statistical Papers Series M No 19/Rev.3, United Nations Department of Economic and Social Affairs Statistics Division 2014) ('Principles and Recommendations for a Vital Statistics System') <http://unstats.un.org/unsd/demographic/standmeth/principles/M19Rev3en.pdf>. 
Statelessness 2014-2024 mention the recording of other life events in a comprehensive civil registration system. ${ }^{37}$

Registration of marriages (or civil partnerships), adoptions and guardianships, changes of name, divorces and other cessation of these statuses, and deaths, may be as critical to assert rights based on identity as birth registration. This includes the right to the nationality of a particular state. Birth in or out of wedlock - most often defined as a formally registered marriage - may create different rights for children to acquire nationality or to inherit property, dependent on the systems for recognition and registration of parentage. Care of a child without registration of a formal adoption or other legal relationship may leave the child rightless within the foster family, and if the child has origins in another country, also stateless. Registration of the death of a pre-deceased parent may be necessary for birth registration to take place, for the child's nationality and other rights to be recognised, or for a spouse to claim a pension or other benefits.

The problem with adopting a target for complete civil registration coverage is, first and foremost, the obvious unattainability of such a target in very many countries within the timeframe of the SDGs. But it is equally challenging to formulate an indicator that would accommodate the immense complexity of civil registration systems around the world. The definition of civil registration employed by the UN is clear that uniformity is indeed not expected across states:

civil registration is defined as the continuous, permanent, compulsory and universal recording of the occurrence and characteristics of vital events pertaining to the population, as provided through decree or regulation in accordance with the legal requirements in each country. ${ }^{38}$

What are these legal requirements? It is possible to start with the very general sorting of civil registration frameworks into civil and common law systems. Legal systems within the civil, or Romano-Germanic, legal tradition tend to be comfortable with comprehensive and centralised civil registration as the basis for recognition of legal capacity and status within the family: incorporating not only registration of births and deaths, but also adoptions, marriages, divorces and changes of name. The Nordic states are among those that have taken this approach the furthest, integrating civil registration into a national population register in which other family relationships are also recorded. ${ }^{39}$ The common law systems found in Britain and its former colonies, however, tend historically to have managed official identity and interactions with the state through multiple registers

37 SDG indicator 17.19.2 includes the "proportion of countries that ... (b) have achieved 100 per cent birth registration and 80 per cent death registration'. This indicator relates not to legal identity, however, but to Target 17.19 on statistical capacity-building, falling under SDG 17, on the need to 'revitalize global partnerships for sustainable development'. See, 'Sustainable Development Goal 17', United Nations Department of Economic and Social Affairs Sustainable Development Knowledge Platform (Web Page, 2015) $<$ https://sustainabledevelopment.un.org/sdg17>. See also Global Action Plan to End Statelessness: 2014-2024 (Report, UNHCR 2014) action 7: Ensure birth registration for the prevention of statelessness' $<$ https://www.unhcr.org/en$\mathrm{au} /$ protection/statelessness/54621bf49/global-action-plan-end-statelessness-20142024.html>.

38 Principles and Recommendations for a Vital Statistics System (n 36) 65 [279] (emphasis added).

39 Ian Watson, 'An Unusually Open Identification Number System: The Icelandic Kennitala' in Ilsen About, James Brown and Gayle Lonergan (eds), Identification and Registration Practices in Transnational Perspective: People, Papers and Practices (Palgrave Macmillan 2013) 132. 
maintained for different purposes (though with the possibility of cross-checks to prevent fraud). Thus a former French territory will have a code on civil status or a family code including comprehensive rules on all forms of civil registration, as well as rules on adoption, or establishing parentage in case of children born out of wedlock; and in some cases also regulating nationality. A former British territory is likely to have a births and deaths registration act, and separate laws on marriage, adoption and citizenship, and perhaps a separate child law also. ${ }^{40}$

The detailed variations of civil registration laws, however, undermine this simple binary. ${ }^{41}$ There are hybrid civil-common law countries (where the colonising power changed); while Islamic and (formerly) communist societies have their own important variants, as do states that have sought to formalise recognition of customary law, or those where civil registration is rather at the family or household level. The construction of civil registration systems both reflects and shapes deeply held social norms about the nature of the family, property rights, and belonging. The efforts of governments to establish or reform registration systems have therefore also created consternation among populations cleaving to different conceptions of the family, marriage and the rights of children; ${ }^{42}$ these clashes have often been visible in the efforts of colonial officials to register 'native' populations. ${ }^{43}$ Anxieties about attribution of status to abandoned children have been perennial; ${ }^{44}$ as have those on the recognition of the fathers of children born out of wedlock. ${ }^{45}$ The more recent development of civil registration frameworks reflects the profound influence of human rights law and norms of non-discrimination on concepts of the family. ${ }^{46}$ Civil registration laws encode the social acceptance (or not) of same-sex partnerships and parenting, ${ }^{47}$ or the right of indigenous peoples to self-identify. ${ }^{48}$

40 In this article, nationality and citizenship are used interchangeably; nationality in relation to international law and, at national level, the term in relevant laws or usage in the document being referred to.

41 Vernon Valentine Palmer, 'Mixed Legal Systems' in Mauro Bussani and Ugo Mattei (eds), The Cambridge Companion to Comparative Law (Cambridge University Press 2012) 368.

42 Neil J Diamant, "Making Love "Legible" in China: Politics and Society during the Enforcement of Civil Marriage Registration, 1950-66' (2001) 29(3) Politics \& Society 447; Osamu Saito and Masahiro Sato, 'Japan's Civil Registration Systems before and after the Meiji Restoration' in Breckenridge and Szreter (n 5) 113.

43 Frederick Cooper, 'Voting, Welfare and Registration: The Strange Fate of the État-Civil in French Africa, 1945-1960' in Breckenridge and Szreter (n 5) 385.

44 Nazan Maksudyan, 'The Fight over Nobody's Children: Religion, Nationality and Citizenship of Foundlings in the Late Ottoman Empire' (2009) 41(Fall) New Perspectives on Turkey 151; Katherine O'Donovan, 'Interpretations of Children's Identity Rights' in Deirdre Fottrell (ed), Revisiting Children's Rights: 10 years of the UN Convention on the Rights of the Child (Kluwer Law International 2000) 73; Sari K Ishii, 'Access to Citizenship for Abandoned Children: How Migrants' Children Become “Stateless” in Japanese Orphanages' (2020) 46 Journal of Ethnic and Migration Studies 1.

45 Marie-Therese Meulders-Klein, 'The Position of the Father in European Legislation' (1990) 4(2) International Journal of Law, Policy and the Family 131.

46 Fareda Banda and John Eekelaar, 'International Conceptions of the Family' (2017) 66(4) International and Comparative Law Quarterly 833.

47 Carl Stychin, 'Family Friendly? Rights, Responsibilities and Relationship Recognition' in Alison Diduck and Katherine O'Donovan (eds), Feminist Perspectives on Family Law (Routledge 2006) 21.

48 Committee on the Rights of the Child, General Comment No 11: Indigenous Children and Their Rights under the Convention, UN Doc CRC/C/GC/11 (12 February 2009); Richard Madden et al, 'Indigenous Identification: Past, Present and a Possible Future' (2019) 35(1) Statistical Journal of the IAOS 23. 
The legal identity field is vastly complicated by these sensitivities and differences of legal approach. It can be difficult enough to manage legal and cultural pluralism within the registration systems of one country. When state boundaries are crossed, the challenges are multiplied. The recognition of civil status documents issued by one set of authorities in other countries is managed by national rules that are as varied as the rules for civil registration itself.

Depending on the country, an assortment of official copies of parental birth, death or marriage certificates may be required to register a child's birth. If the child's birth is in a different country from the one where these documents were issued, the official copies must be obtained from the country of origin, presented in a form accepted by the host country and usually transcribed into its national records. Non-recognition of a foreign-registered civil status event means that it lacks legal effect, leaving (for example) marriages invalid in one country or the other, or still in place despite a registered divorce. If a person's civil status documents are not recognised in another jurisdiction, the rights that depend on these documents may also be unrecognised: the same child may therefore be born in wedlock for the authorities of one country and out-of-wedlock for another. ${ }^{49}$ On top of these challenges related to registration in the country of birth, consular registration and/or transcription into the records of the state of origin is in many cases necessary if the child's right to the nationality of one or both parents is to be recognised. It is also likely that the parents will need a valid passport or other identity document, and if neither is a national of the country where their child is born, often also a visa showing legal presence in the country. ${ }^{50} \mathrm{~A}$ finding of an error at any stage in these processes can sometimes result in the retroactive loss of nationality apparently held legitimately over many years. ${ }^{51}$

Already exhausting for legal migrants in the formal sector, for refugees and irregular migrants of few resources (financial or social) these games of paperchase make the recognition of legal identity and nationality ever more fragile. 52

These problems of conflicts of law place us in the domain of The Hague Conference of Private International Law ('The Hague Conference'), an 85member international organisation established in 1955 with the objective 'to work for the progressive unification of the rules of private international law'. 53 The Hague Conference has undertaken some efforts to simplify the mutual recognition

49 In a case before the United Kingdom courts, an applicant was left stateless when Mauritius did not accept that she was her father's legitimate daughter on the basis of the documents produced; while the UK did, which meant that she had not retained British citizenship when Mauritius became independent: $R v$ Secretary of State for the Home Department, ex $p$ Mahaboob Bibi [1985] Imm AR 134, affirmed by the Court of Appeal at [1987] Imm AR 340, discussed in Laurie Fransman, Adrian Berry and Alison Harvey, Fransman's British Nationality Law ( $3^{\text {rd }}$ edn, Bloomsbury Professional 2011) ch 8.12.

50 Bronwen Manby, Preventing Statelessness among Migrants and Refugees: Birth Registration and Consular Assistance in Egypt and Morocco (LSE Middle East Centre Paper Series No 27, 2019).

51 Gerard-René de Groot and Patrick Wautelet, Reflections on Quasi-Loss of Nationality in Comparative, International and European Perspective (CEPS Papers in Liberty and Security in Europe No 66, Centre for European Policy Studies August 2014) $<$ https://www.ceps.eu/ceps-publications/reflections-quasi-loss-nationality-comparativeinternational-and-european-perspective/ $>$.

52 Pardis Mahdavi, Crossing the Gulf: Love and Family in Migrant Lives (Stanford University Press 2016); Catherine Allerton, 'Impossible Children: Illegality and Excluded Belonging among Children of Migrants in Sabah, East Malaysia' (2018) 44(7) Journal of Ethnic and Migration Studies 1081.

53 Statute of The Hague Conference on Private International Law (The Hague Conference on Private International Law, entered into force 19 July 1955) art 1. 
of civil registration documents, most importantly through the adoption of the 1961 Convention to Abolish the Requirements of Legalisation for Foreign Public Documents ('Apostille Convention'). ${ }^{54}$ More recently it has launched an initiative to facilitate the recognition of foreign judicial decisions relating to parentage, in particular in the new context of international surrogacy arrangements. ${ }^{55}$ The Commission Internationale de l'État Civil (International Commission on Civil Status) ('ICCS'), an intergovernmental organisation established in 1950, aims specifically 'to facilitate international cooperation in civil status matters' and has adopted 34 conventions to that effect, including Convention No 13 of 1973 aimed at reducing statelessness caused by gender discrimination in nationality law; Convention No 16 of 1976 on multilingual certificates; and Convention No 17 of 1977, with objectives similar to the Apostille Convention for the reduction of the burden of legalisation of foreign documents. ${ }^{56}$ In 2010 , the ICCS published a study on the comparative laws and policies of its 15 member states (at that time), highlighting the great variation in relation to proof of civil status for irregular migrants. ${ }^{57}$ But the ICCS has gradually lost support and had only six member states as of 2020; its relevance diminished, it seems, by low levels of ratification of its treaties, the lack of political backing from some core states and the overlapping of different institutional efforts to resolve these questions. Most (current or former) ICCS states are members of the European Union, and since 1997 the Court of Justice of the European Union has held that the certificates and other documents issued by one EU member state must be recognised by other member states, 'unless their accuracy is seriously undermined by concrete evidence relating to the individual case in question'. ${ }^{58}$ More recently, the EU has attempted to take steps to resolve the 'extremely complex international legal

54 Convention to Abolish the Requirement of Legalisation for Foreign Public Documents (The Hague Conference on Private International Law, opened for signature 5 October 1961, entered into force 24 January 1965).

55 The Hague Conference of Private International Law, Parentage/Surrogacy Project, launched 2011, documents collected at: Experts' Group on the Parentage/Surrogacy Project, 'The Parentage/Surrogacy Project', The Hague Conference of Private International Law (Web Page) $<$ https://www.hcch.net/en/projects/legislative-projects/parentage-surrogacy $>$. See, eg, Advisory Opinion Concerning the Recognition in Domestic Law of a Legal Parent-Child Relationship between a Child Born through a Gestational Surrogacy Arrangement Abroad and the Intended Mother (Requested by the French Court of Cassation) (Advisory Opinion) (European Court of Human Rights, Request No P16-2018-001, 10 April 2019).

56 Convention No 13 to Reduce the Number of Cases of Statelessness (International Commission on Civil Status, opened for signature 13 September 1973) ('Convention No 13'). Convention No 13 had seven states parties; now superseded by CEDAW (n 33). Convention No 16 on the Issue of Multilingual Extracts from Civil Status Records (International Commission on Civil Status, opened for signature 8 September 1976) ('Convention No 16'). Convention No 16 has 24 states parties, the most widely ratified and used. Convention No 17 on the Exemption from Legalisation of Certain Records and Documents (International Commission on Civil Status, opened for signature 15 September 1977) ('Convention No 17'). Convention No 17 has 10 states parties. Conventions 26 to 34, the most recent, have less than five ratifications each, see generally 'Conventions', International Commission on Civil Status (Web Page) $<\mathrm{http}$ ://www.ciec1.org/>. For an outline of the work of the Commission see Chantal Nast, 'Aspects d'état civil: aperçu des activités de la Commission Internationale de l'État Civil' (Colloque, Centre de Droit Privé Fondamental, Université de Strasbourg 7 December 2012) $<$ http://cdpf.unistra.fr/fileadmin/upload/CDPF/Colloques/La_reforme_du_nom_de_1_enfant et_de_1_autorite_parentale/CIEC-CNast_Colloque_7.12.2012.pdf $>$.

57 Persons Deprived of Civil-Status and Identity Documents ("Undocumented Migrants") (Memorandum, International Commission on Civil Status October 2010).

58 Eftalia Dafeki v Landesversicherungsanstalt Württemberg (C-336/94) [1997] ECR I-06761, [21]. 
mosaic' in relation to civil status documents, ${ }^{59}$ and an EU regulation came into force in 2019 that aims to reduce costs and shorten lengthy procedures for mutual recognition of a range of public documents. ${ }^{60}$ But all these efforts are limited in their ambition and scope: not even the EU regulation aims to harmonise the great variety of policy rules among member states regarding verification of facts stated in foreign civil status documents. ${ }^{61}$

Agreements on the regulation of private international law thus seem to have the potential to resolve these issues, to 'focus the analysis on the migrant as an individual rather than on the state's interests' when it comes to global migration governance. ${ }^{62}$ But progress so far is not encouraging.

Public international law, moreover, provides no right to the consular assistance that is needed by a person navigating these cross-border registration labyrinths. It protects the right of a state to assist its nationals (should it so wish), and the rights of migrants to be informed of the availability of the assistance that does exist, but does not establish an obligation for states to provide assistance. ${ }^{63}$ There is only a somewhat limp commitment in the Global Compact for Safe, Orderly and Regular Migration of 2018, to 'ensure adequate, timely, reliable and accessible consular documentation to our nationals residing in other countries, including identity and travel documents'. ${ }^{64}$ The language was watered down from the initial draft in order to reduce the focus on rights and increase the focus on control. 65

59 Mariolina Eliantonio, Silvia Brunello and Hanno von Freyhold, Life in Cross-Border Situations in the EU: A Comparative Study on Civil Status (Study, European Parliament

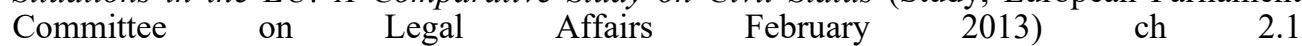
$<$ http://www.europarl.europa.eu/RegData/etudes/etudes/join/2013/474395/IPOLJURI_ET(2013)474395_EN.pdf $>$. See also Birgit Feldtmann et al, Facilitating Life Events (Final Report, European Commission, DG JLS - Directorate-General for Justice, Freedom and Security October 2008) $<$ http://www.freyvial.de/Publications/Civil_Status_in_Europe_Fullreport.pdf $>$ and the work of the European Association of Civil Registrars $<\overline{\mathrm{htt}} \overline{\mathrm{s}} \mathrm{s} / / \mathrm{evs}-\mathrm{e}$. $.0 \mathrm{rg} / \mathrm{en} / \mathrm{explanations} />$.

60 Regulation (EU) 2016/1191 of the European Parliament and of the Council of 6 July 2016 on Promoting the Free Movement of Citizens by Simplifying the Requirements for Presenting Certain Public Documents in the European Union and Amending Regulation (EU) No 1024/2012 [2016] OJ L 200/1. See also Alenka Prvinšek Persoglio, 'State Obligation to Establish Legal Identity in Comparative Perspective', London School of Economics Middle East Centre (Blog Post, 1 May 2019) <https://blogs.lse.ac.uk/mec/2019/05/01/stateobligation-to-establish-legal-identity-in-comparative-perspective/>.

61 Gerard-René de Groot and David de Groot, 'Recognition of Civil Status (Certificates), with Special Attention to Secondary Recognition of Documents Already Recognized in Another Member State' in André Janssen and Hans Schulte-Nölke (eds), Researches in European Private Law and Beyond - Contributions in Honour of Reiner Schulze's Seventieth Birthday (Nomos 2020) 283.

62 Sabine Corneloup, 'Can Private International Law Contribute to Global Migration Governance?' in Horatia Muir Watt and Diego P Fernández Arroyo (eds), Private International Law and Global Governance (Oxford University Press 2014) 301, 302.

63 Vienna Convention on Consular Relations, opened for signature 24 April 1963, 596 UNTS 261 (entered into force 19 March 1967) art 5; International Convention on the Protection of the Rights of All Migrant Workers and Members of their Families, opened for signature 18 December 1990, 2220 UNTS 3 (entered into force 1 July 2003), arts 7, 65(2); The Right to Information on Consular Assistance in the Framework of the Guarantees of the Due Process of Law (Advisory Opinion) (Inter-American Court of Human Rights, Series A No 16, 1 October 1999).

64 Global Compact for Safe, Orderly and Regular Migration, GA Res 73/195, UN GOAR, $73^{\text {rd }}$ sess, Agenda Items 14 and 119, UN Doc A/RES/73/195 (11 January 2019, adopted 19 December 2018) annex 12 [20(c)].

65 Amal de Chickera, 'GCM Commentary: Objective 4: Ensure That All Migrants Have Proof of Legal Identity and Adequate Documentation', Refugee Law Initiative Blog (Blog Post, 8 November 2018) <https://rli.blogs.sas.ac.uk/2018/11/08/gcm-commentary-objective-4/>. 
The situation of refugees and their children is particularly challenging. ${ }^{66}$ There are provisions in the 1951 Convention Relating to the Status of Refugees intended to govern the recognition or substitution of personal status documents issued in another country or that would normally be obtained from a consulate, but little guidance on the practical steps required to fulfil these obligations. ${ }^{67}$ Even if substitute documents are issued, states do not always accord them the same status as originals. ${ }^{68} \mathrm{UNHCR}$ will attempt to facilitate birth registration for the children of refugees, but it is the host government that must carry this out. ${ }^{69}$ A refugee status document will usually serve as sufficient proof of identity and legal status in the host country, enabling births and other civil status events to be registered there. However, a person seeking to register a birth may also require consular assistance to obtain copies of the other documents required (such as a marriage certificate, or the death certificate of the other spouse, if relevant). In some cases where a person seeks documents from a consulate, the host country may consider that the refugee 'voluntarily re-availed himself of the protection of the country of nationality' and therefore, though UNHCR urges otherwise, that refugee protection ceases to apply. ${ }^{70}$ For the same reasons, refugees cannot generally approach the authorities of their country of origin in order to transcribe information in a birth certificate into that country's registers, since to do so would put their refugee status at risk, or (even if not officially recognised as refugees) they may be afraid of the consequences. These difficulties mean that the nationality of refugee children born outside their parents' state of nationality often remains legally uncertain, unless the host country provides a right to nationality based on birth and/or residence in the country. ${ }^{71}$ Even if parents and child can

66 Jinske Verhellen, 'Cross-Border Portability of Refugees' Personal Status' (2018) 31(4) Journal of Refugee Studies 427; Vincent Chetail, 'Les relations entre droit international privé et droit international des réfugiés: histoire d'une brève rencontre' (2014) 141(2) Journal du Droit International 447.

67 Article 12 of the Convention relates to recognition of personal status, while art 25 provides for states to provide administrative assistance to refugees, including delivery of 'such documents or certifications as would normally be delivered to aliens by or through their national authorities': Convention Relating to the Status of Refugees, opened for signature 28 July 1951, 189 UNTS 150 (entered into force 22 April 1954), ('1951 Refugee Convention'). See also James C Hathaway, The Rights of Refugees Under International Law (Cambridge University Press 2005) chs 3.2.4, 4.10. Article 25 is also considered in Summary Conclusions: Expert Roundtable on the Right to Family Life and Family Unity in the Context of Family Reunification of Refugees and Other Persons in Need of International Protection (Report, UNHCR 4 December 2017); Frances Nicholson, "The "Essential Right" to Family Unity of Refugees and Others in Need of International Protection in the Context of Family Reunification' (Legal and Protection Policy Research Series, UNHCR 2018). Similar provisions to those in the 1951 Refugee Convention are included within arts 12 and 25 of the 1954 Convention relating to the Status of Stateless Persons; there is no guidance on these obligations for stateless persons who are not also refugees: Convention Relating to the Status of Stateless Persons, opened for signature 28 September 1954, 360 UNTS 117 (entered into force 6 June 1960).

68 A point considered in relation to family reunification in Tanda-Muzinga $v$ France (European Court of Human Rights, Chamber, Application No 2260/10, 10 July 2014).

69 UNHCR Executive Committee, Conclusion on Civil Registration (No 111 (LXIV), 17 October 2013).

70 Article 1C of the 1951 Refugee Convention (n 67) provides that: 'This Convention shall cease to apply to any person falling under the terms of section A if: (1) He has voluntarily re-availed himself of the protection of the country of his nationality;...'. For commentary, see Handbook on Procedures and Criteria for Determining Refugee Status and Guidelines on International Protection under the 1951 Convention and the 1967 Protocol Relating to the Status of Refugees (Reissued, UNHCR 2019) 30 [121].

71 Gábor Gyulai, 'The Long-Overlooked Mystery of Refugee Children's Nationality', The World's Stateless: Children (Report, Institute on Statelessness and Inclusion February 2017). 
return to the country of origin, exceptional procedures may be needed to recognise the child's status in the absence of consular registration and transcription of a birth certificate. ${ }^{72}$

\section{CiVIL REGISTRATION IN THE UN SYSTEM}

The UN system has historically not done much to address these challenges. Civil registration is 'owned' by the Statistical Commission, whose secretariat is the Statistics Division of the Department of Economic and Social Affairs. The function of civil registration, the legal registration of vital events, is combined with the collection of vital statistics based on that registration, to provide information on the population of a country.

The first edition of the UN Handbook of Vital Statistics Methods, published in 1955, emphasised the primary value of civil registration as legal, and only secondarily as a source of vital statistics. In poorer countries where civil registration coverage is incomplete, surveys are more practical tools to gather information needed for government planning. ${ }^{73}$ But the housing of international coordination of efforts to improve civil registration within the statistical arm of the UN led the statistics aspects of what came to be known as civil registration and vital statistics ('CRVS') to dominate, important as they are to richer countries where registration is nearly complete, for the purposes of state planning and to guide interventions in public health (especially through registration of cause of death). ${ }^{74}$ Only a 1998 publication on preparation of a legal framework placed stronger emphasis on registration of legal status and protection of individual rights. ${ }^{75}$ The current UN Principles and Recommendations for a Vital Statistics System, adopted in 2014, continue to note that 'the essential purpose of civil registration is to furnish legal instruments of direct interest to individuals'; ${ }^{76}$ but a scant handful of pages in the 150 page document relate to the legal aspect.

Civil registration for whatever purpose was for many decades a generally neglected part of the international agenda. This changed around the turn of the millennium. UNICEF placed new emphasis on the importance of birth registration

72 For the situation of the 'red-coded' former Liberian refugees in West Africa, see Bronwen Manby, Nationality, Migration and Statelessness in West Africa (Study, UNHCR and International Organisation $\quad$ for $\quad$ Migration 2015 ) $<$ https://www.unhcr.org/ecowas2015/Nationality-Migration-and-Statelessness-in-WestAfrica-REPORT-EN.pdf>.

73 Statistical Office of the United Nations, Handbook of Vital Statistics Methods (United Nations, Studies in Methods Series F No 7, 1955) ch 1(B) $<$ https://unstats.un.org/unsd/demographic-social/Standards-andMethods/files/Handbooks/crvs/Series_F7-E.pdf>.

74 van der Straaten (n 8) 20-21.

75 United Nations Statistics Division, Handbook on Civil Registration and Vital Statistics Systems: Preparation of a Legal Framework (United Nations, Studies in Methods Series F No 71, 1998) ch $1<\mathrm{https}$ ://unstats.un.org/unsd/publication/SeriesF/SeriesF_71E.pdf $>$. The Handbook also raised concerns about the issue of a single number to a person, which 'removes the personal characteristics that have traditionally served to establish a person's identity': at 16 [39].

76 Principles and Recommendations for a Vital Statistics System (n 36) 66 [286]. 
for child protection. ${ }^{77}$ Plan International conducted a major global campaign on birth registration from 2005 to 2009, launched by Archbishop Desmond Tutu. ${ }^{78}$ The Lancet published a ground-breaking series of articles in 2007 that drew attention to the 'scandal of invisibility' caused by lack of civil registration, and described the neglect of global CRVS systems as 'the single most critical failure of development over the past 30 years'. ${ }^{79}$ The Inter-American Development Bank also took up civil registration as an important issue both for economic development and for individual access to essential services such as health and education. ${ }^{80}$ An initiative to improve lamentable rates of civil registration in Africa was launched by a consortium of international agencies with the African Union in 2010. ${ }^{81}$ In late 2014, governments in the Asia-Pacific region proclaimed a 'CRVS Decade' (2015-24). ${ }^{82}$ This growing consensus contributed to the recognition of 'legal identity' and birth registration within the SDGs.

\section{LEGAL IDENTITY, DigITAL IDENTITY AND DEVELOPMENT}

Development actors have now taken up the 'legal identity' SDG target with enthusiasm. In 2014, the World Bank created a unit to coordinate its work on 'identification for development', recognising that lack of identity documents can create significant social and economic exclusion, and thus form a drag on

77 Unity Dow, 'Birth Registration: The "First" Right' in Catharine Way (ed), The Progress of Nations: The Nations of the World Ranked According to Their Achievements in Fulfilment of Child Rights and Progress for Women (UNICEF 1998) $<$ https://www.unicef.org/about/history/files/pub_pon98_en.pdf $>$; United Nations Children's Fund, 'Birth Registration Right from the Start', Innocenti Digest (March 2002) $<$ https://www.unicef-irc.org/publications/pdf/digest9e.pdf $>$.

78 Claire Cody, Count Every Child: The Right to Birth Registration (Campaign Report, Plan International, 2009); Simon Heap and Claire Cody, 'The Universal Birth Registration Campaign' (2009) 32(April) Forced Migration Review 20.

79 Richard Horton, 'Counting for Health' (2007) 370(9598) The Lancet 1526. The full series can be viewed online: see 'Who Counts?', The Lancet (Web Page, 30 October 2007) $<$ https://www.thelancet.com/series/who-counts $>$. The series was updated in 2015: see 'Counting Births and Deaths', The Lancet (Web Page, 11 May 2015) $<\mathrm{http}$ ///www.thelancet.com/series/counting-births-and-deaths $>$.

80 See, eg, Mia Harbitz, 'The Civil Registry: A Neglected Dimension of International Development' (Technical Note No IDB-TN-542, Inter-American Development Bank May 2013) <https://publications.iadb.org/publications/english/document/The-Civil-Registry-ANeglected-Dimension-of-International-Development.pdf>; Mia Harbitz and Bettina BoekleGiuffrida, Democratic Governance, Citizenship, and Legal Identity: Linking Theoretical Discussion and Operational Reality (Working Paper, Inter-American Development Bank, May 2009)

$<$ https://publications.iadb.org/bitstream/handle/11319/4300/Democratic\%20Governance\%2 c\%20Citizenship\%2c\%20and\%20Legal\%20Identity.pdf $>$.

81 Africa Programme on Accelerated Improvement of Civil Registration and Vital Statistics (Web Page) <http://www.apai-crvs.org/>.

82 See Asian and Pacific Civil Registration and Vital Statistics Decade 2015-2024 (Report, Get Everyone in the Picture 2015) $<$ https:/getinthepicture.org/sites/default/files/resources/Asian_and_Pacific_Civil_Registrati on_and_Vital_Statistics_Decade2015-2024_Booklet.pdf> 
economic development generally. ${ }^{83}$ Development think tanks agree with this assessment. ${ }^{84}$

Important as birth registration is recognised to be, however, achieving complete coverage of a population by improving registration at the time of birth would necessarily involve a wait of 70 years or more. Although an effort to improve late registration of births and other events is a potential solution (successfully implemented in South Africa, for example), ${ }^{85}$ the emphasis has shifted to the broader, undefined, target. ${ }^{86}$ Technical professionals also tend towards a certain impatience with the complexities of legal status in private or public international law. The rapid advance of digital technology leads many to the conclusion that the best way to achieve the SDG legal identity target is 'through digital identity systems, central registries storing personal data in digital form and credentials that rely on digital, rather than physical, mechanisms to authenticate the identity of their holder'. ${ }^{87}$ Low-income countries can, it is argued, 'leapfrog' the paper-based stage, and move straight to digital identification. ${ }^{88}$ Data protection is recognised as a concern, but one that can be managed. ${ }^{89}$ In practice, digital identification programmes, most often based on biometrics, are being rolled out at a 'dizzying pace across the developing world' - with or without the support of traditional development agencies. ${ }^{90}$ Among the actors that have jumped on the 'legal identity' target are biometric tech companies, sometimes interested more in rent-seeking

83 Vyjayanti T Desai, Anna Diofasi Metz and Jing Lu, 'The Global Identification Challenge: Who Are the 1 Billion People without Proof of Identity?', World Bank Blogs (Blog Post, 25 April 2018) <https://blogs.worldbank.org/voices/global-identification-challenge-who-are-1billion-people-without-proof-identity>.

Elizabeth Stuart et al, 'The Data Revolution: Finding the Missing Millions' (Research Report No 3, Overseas Development Institute April 2015) $<$ https://www.odi.org/sites/odi.org.uk/files/odi-assets/publications-opinion-files/9604.pdf>; Gelb and Diofasi Metz (n 9).

85 Jaap van der Straaten and Anna Zita Metz, South Africa ID Case Study (Working Paper No 137142, World Bank, 1 May 2019) $<$ http://documents.worldbank.org/curated/en/315081558706143827/South-Africa-ID-CaseStudy>.

86 The World Bank has produced a dataset on the numbers of people without 'proof of legal identity' that provides a global estimate of one billion people without identity documents; but the methodology depends on existing data, which is very incomplete, and does not include coverage of birth registration or certificates for those over five years old: 'Identification for Development (ID4D) Global Dataset', The World Bank (Web Page, 2018) $<$ https://id4d.worldbank.org/global-dataset>.

87 Joseph J Atick et al, 'Spotlight 4: Enabling Digital Development: Digital Identity' in World Development Report 2016: Digital Dividends (Report, World Bank 2016) 194-97.

88 Alan Gelb and Julia Clark, Identification for Development: The Biometrics Revolution (Working Paper No 315, Center for Global Development, 2013) 3, 46; World Development Report 2016: Digital Dividends (Report, World Bank 2016) 154.

89 ID Enabling Environment Assessment: Guidance Note (Working Paper No 137288, World Bank, 1 January 2018) <https://id4d.worldbank.org/legal-assessment>; 'Good ID Explained', Good ID (Web Page) < https://www.good-id.org/en/about/>.

90 Gelb and Diofasi Metz (n 9) ix. 
than human rights or development 91 — thus undermining the promised cost savings of digital ID. ${ }^{92}$

One frequently cited example of the benefits of leapfrogging the overlong process of civil registration is the Indian Aadhaar ('foundation') program, established in 2009, which issues a 12-digit unique identity number to any resident of India, after collecting biometric data and other basic information. ${ }^{93}$ As of 2019, 95 per cent of adults and 75 per cent of children in India - more than 1.2 billion people - had been issued an Aadhaar number. ${ }^{94}$ The Aadhaar register provides a short cut to proof of individual identity, concentrating only on uniqueness and not on other elements of identity; it seeks to sidestep difficult questions around determination of eligibility for citizenship, and bypasses the National Register of Citizens and national identity card proposed since 2003. ${ }^{95}$ The Aadhaar approach is favoured by the World Bank, and promoted elsewhere (for example in West Africa). .96

However, even as biometric registration programmes proceed apace, enrolment into new national registers has in other countries not been delinked from nationality. The legislation establishing national identity registers generally requires governments to record legal status - as citizen or alien - as part of the registration process, even if it also authorises the collection of biometric data (not always the case, even if biometric data is being collected). As these programmes are rolled out they are often accompanied by a strong assertion of biometric registration as a necessary component of national security, providing a 'single source of truth' for all personal data (a term derived from information systems design), to be certain that citizens are clearly distinguished from foreigners, and to eliminate fraudulent acquisition of documents and access to the benefits and rights granted to citizens. ${ }^{97}$

91 Mushtaq Khan and Pallavi Roy, Digital Identities: A Political Settlements Analysis of Asymmetric Power and Information (Working Paper No 15, Anti-Corruption Evidence Research Consortium School of Oriental and African Studies University of London, October 2019) < <https://ace.soas.ac.uk/wp-content/uploads/2019/11/ACE-WorkingPaper015DigitalIdentities-191004.pdf>.

92 Julia Clark, Public Sector Savings and Revenue from Identification Systems: Opportunities and Constraints (Report, World Bank 2018) $<$ http://documents.worldbank.org/curated/en/745871522848339938/Public-Sector-Savingsand-Revenue-from-Identification-Systems-Opportunities-and-Constraints.pdf $>$; Olivia White et al, Digital Identification: A Key to Inclusive Growth (Report, McKinsey Global Institute 17 April 2019) <https://www.mckinsey.com/business-functions/mckinseydigital/our-insights/digital-identification-a-key-to-inclusive-growth>.

93 Vivek Raghavan, Sanjay Jain and Pramod Varma, 'India Stack - Digital Infrastructure as Public Good' (2019) 62(11) Communications of the ACM 76.

94 State of Aadhaar: A People's Perspective (Report, Dalberg and Omidyar Network India 2019) ('State of Aadhaar: A People's Perspective'). See below n 106.

95 Srijoni Sen, A Decade of Aadhaar: Lessons in Implementing a Foundational ID System (ORF Issue Brief No 292, Observer Research Foundation May 2019) $<$ https://www.orfonline.org/research/a-decade-of-aadhaar-lessons-in-implementing-afoundational-id-system-50464/>.

96 'West Africa Unique Identification for Regional Integration and Inclusion (WURI) Project', World Bank (Web Page) <https://projects.worldbank.org/en/projects-operations/projectdetail/P161329>.

97 See, eg, Robert Mugo, Ministry of Information Communications and Technology, Kenya, 'Kenya National Integrated Identity Management Systems (NIIMS)' (Conference Presentation, ID4Africa Conference, 18 June 2019) $<$ https://www.id4africa.com/2019_event/presentations/PS1/2-Robert-Mugo-Kenya.pdf $>$; for a summary of the issues in Kenya, see Varun Baliga, 'Kenya's Huduma Namba: Ambition Fraught with Risk', Ikigai Law (Web Page, 22 April 2020) $<$ https://www.ikigailaw.com/kenyas-huduma-namba-ambition-fraught-with-risk/>. 
The dimension of citizenship thus cannot be ignored while still respecting the SDG objective to 'leave no one behind'. 98

\section{The Dangers of Short Cuts: Population Registration AND THE}

\section{CREATION OF STATELESSNESS}

The countries where new identity registers are expected to be of the greatest benefit to the economy, to the state and to individuals, are those where the highest percentage of the population is currently unregistered. The process of enrolling those with no pre-existing official documents into a national population register that records legal status in the country requires a multitude of individual decisions about that status, whether a person is a citizen or not; and if not a citizen, whether they have another status entitling them to remain in the country. But there are many millions of people in the world whose citizenship status is simply not clear: a smaller number than those without identity documents (for many of whom citizenship will be uncontroversial), but still a very substantial figure. Among them, those facing discrimination of various kinds may well be stateless - but this would only become apparent as requirements to acquire and produce documents become more pervasive.

Where new systems are adopted without considering the underlying legal and policy frameworks on nationality and family relations there are risks of generating new forms of exclusion. Indeed, the creation of new population registers has always been a danger point for the creation of stateless populations. In Lebanon, Syria, and the Gulf States, the descendants of those who were not included in the population registries created at independence remain stateless today, even though their ancestors should have been entitled to nationality under the law. ${ }^{99}$ Similar problems arose when new registers were established in the successor states of the former Yugoslavia and Soviet Union. ${ }^{100}$ More recently, a campaign group representing black Mauritanians, Touche pas à ma nationalité, accused the Mauritanian government of 'biometric genocide' in its implementation of a new identity card system coupled with amendments to the nationality code in 2010. ${ }^{101}$ In the Dominican Republic, support for new identity systems was instrumentalised as part of a drive to remove recognition of Dominican nationality from those of

98 Alan Gelb and Bronwen Manby, 'Has Development Converged with Human Rights? Implications for the Legal Identity SDG', CDG Policy Blogs (Blog Post, Center for Global Development, 3 November 2016) <https://www.cgdev.org/blog/has-developmentconverged-human-rights-implications-legal-identity-sdg>; Gelb and Diofasi Metz (n 9) 42.

99 Rania Maktabi, 'The Lebanese Census of 1932 Revisited. Who Are the Lebanese?' (1999) 26(2) British Journal of Middle Eastern Studies 219; Zahra Albarazi, The Stateless Syrians (Report, Tilburg University Statelessness Programme May 2013); Zahra Albarazi, Regional Report on Citizenship: The Middle East and North Africa (GLOBALCIT Comparative Report No 2017/03, European University Institute Robert Schuman Centre for Advanced Studies November 2017); Claire Beaugrand, Stateless in the Gulf: Migration, Nationality and Society in Kuwait (IB Tauris 2017).

100 Annelies Lottmann, 'No Direction Home: Nationalism and Statelessness in the Baltics' (2008) 43(3) Texas International Law Journal 503; Report on Statelessness in South Eastern Europe (Report, UNHCR September, 2011); Marjorie Farquharson, Statelessness in Central Asia (Report, UNHCR May 2011).

101 Zekeria Ould Ahmed Salem, “"Touche pas à ma nationalité”: enrôlement biométrique et controverses sur l'identification en Mauritanie' (2018) 152(4) Politique africaine 77; Bronwen Manby, Citizenship in Africa: The Law of Belonging (Hart Publishing 2018) ch 7.6. 
Haitian descent. 102 The new national number and biometric identity card introduced by Sudan since the secession of South Sudan in 2011 was in practice depriving people who had never considered themselves South Sudanese of their Sudanese nationality. ${ }^{103}$ Similar patterns have been visible in Kenya, Côte d'Ivoire and many other countries. At the same time, the long struggles for the establishment of independent electoral commissions to create fairer elections are being undermined by the move to make possession of a national identity card under the firm control of the executive - a universal prerequisite to register to vote. The saving in cost by avoiding multiple registration processes has logic; but a lack of independent oversight of the determination of who is a citizen has its own non-financial costs.

In countries with low rates of documentation, immigrant populations have historically been able to dissolve into the population by the simple route of change or choice of name. ${ }^{104}$ As official identities become fixed, this form of 'naturalisation' is no longer possible, making gaps in the law on acquisition of nationality — at birth or later — ever more significant. And as multiple registries for different purposes are merged into one national database, the stakes of an entry on the register are raised; meaning that the exclusion of those whose status is perceived to be doubtful is also more likely.

The World Bank's Principles on Identification for Sustainable Development, endorsed by a wide range of international agencies and private sector actors, include a commitment to non-discrimination, to provide 'legal identification to all residents - not just citizens'. ${ }^{105}$ This is a good principle. However, the commitment does not address the fact that universal coverage of identity documents that record legal status in the country is not at all empowering for those who fail whatever tests are imposed and are issued an identity number or card as a non-citizen (especially, but not only, if no other citizenship is simultaneously confirmed). For those individuals previously treated as citizens in most contexts, a registration process that determines that they are not citizens - coupled with a new requirement to produce ID for all official transactions - may well be worse than a situation where a much larger group was marginalised for lack of an identity document (even if those who now have a 'citizen' ID benefit as intended).

This is the perceived attraction of adult registration processes delinked from legal status. But even the Aadhaar register in India, which in principle could avoid these problems, has proved impossible to roll out in regions where legal status is particularly controversial, most of all in the north-eastern state of Assam. At the same time, less than one per cent of those enrolled in Aadhaar did not already have

102 'Illegal People': Haitians and Dominico-Haitians in the Dominican Republic (Human Rights Watch Report Vol 14 No 1(B), Human Rights Watch April 2002); 'Without Papers, I Am No One': Stateless People in the Dominican Republic (Report, Amnesty International 2015); Eve Hayes De Kalaf, 'Making Foreign: Legal Identity, Social Policy and the Contours of Belonging in the Contemporary Dominican Republic' in Gibrán Cruz-Martínez (ed), Welfare and Social Protection in Contemporary Latin America (Routledge 2019) 99.

103 Munzoul AM Assal, 'Struggles of Citizenship in Sudan' in Engin F Isin and Peter Nyers (eds), Routledge Handbook of Global Citizenship Studies (Routledge 2014) 196; Nationality and Statelessness in Sudan following the Secession of South Sudan (Draft Report Human Rights Centre University of Khartoum 2016) (on file with the author) .

104 See, eg, Shane Doyle, 'Parish Baptism Registers, Vital Registration and Fixing Identities in Uganda' in Breckenridge and Szreter (n 5) 277.

105 Principles on Identification for Sustainable Development: Toward the Digital Age (Principles, World Bank 2018) ('Principles on Identification for Sustainable Development') $8 \quad$ http://documents1.worldbank.org/curated/en/213581486378184357/pdf/Principles-onidentification-for-sustainable-development-toward-the-digital-age.pdf $>$. 
at least one form of identity document. ${ }^{106}$ The Aadhaar number has also not prevented, and perhaps facilitated, the politicisation of access to citizenship under the government of Narendra Modi, and the 'screening out' of minorities from entitlement to citizenship and an entry in the National Population Register and newly revived National Register of Citizens. ${ }^{107}$ The government is reported as intending to link the Aadhaar platform to the NRC, rather than preserving the separation of Aadhaar from citizenship, and to refuse Aadhaar numbers to those not in the NRC. ${ }^{108}$ Although one could imagine that the computerised record of identification and authentication provided by Aadhaar could in due course facilitate resolution of the more complex issues, by creating sufficient digital traces of a person's existence over time to justify recognition of citizenship, this is not what has happened (or seems likely to happen) in practice. Meanwhile, average birth registration coverage - which records place and date of birth and identity of parents, on the basis of which citizenship could in most cases be determined, but also does not confirm legal status in the country - is now close to 90 per cent across India; and, in contrast to Aadhaar registration, reaches 100 per cent in Assam. ${ }^{109}$

\section{CONCLUSION: LEGAL IDENTITY, BIRTH REgISTRATION AND STATELESSNESS}

The first step to understanding the potential impact of the SDG Target 16.9 to 'provide legal identity' is to gloss the meaning of this deceptively simple language. A person's legal identity, the identity they have in law, is separate from the question of whether they have been formally identified and registered by state authorities. Target 16.9 is therefore best understood (if it is to have a positive impact) as an objective related to the obligation to enable proof of legal identity, through a process of registration, in most cases followed by issue of a token -

106 State of Aadhaar Report 2017-18 (Report, ID Insight and Omidyar Network India May 2018) 5; State of Aadhaar: A People's Perspective (n 94) ch 2.2. As of May 2020, coverage was reported to reach an average 88.6 per cent of the population across all states; but only 22.5 per cent in Assam, the lowest: State/UT wise Aadhaar Saturation (Report, Unique Identification Authority of India 31 May 2018) <https://uidai.gov.in/images/state-wiseaadhaar-saturation.pdf $>$.

107 'An Open Letter to the Citizens of India: India Does Not Need the CAA-NPR-NRIC', Constitutional Conduct (Blog Post, 9 January 2020) $<$ https://constitutionalconduct.com/2020/01/09/an-open-letter-to-the-citizens-of-india-indiadoes-not-need-the-caa-npr-nric/>; Niraja Gopal Jayal, 'Faith-Based Citizenship: The Dangerous Path India Is Choosing,, The India Forum (online, 1 November 2019) $<$ https://www.theindiaforum.in/article/faith-criterion-citizenship >; Sajaudeen Nijamodeen Chapparban, 'Religious Identity and Politics of Citizenship in South Asia: A Reflection on Refugees and Migrants in India' (2020) 63(1) Development 52; Abdessalam Jaldi, The Indian Citizenship Amendment Act (CAA) (Policy Brief PB-20/23, Policy Centre for the New South 6 April 2020) <https://www.policycenter.ma/publications/indian-citizenship-amendmentact-caa>.

108 Ipsita Chakravarty, 'In Assam, Merging NRC Update with Aadhaar Enrolment Leads to Fresh Questions', Scroll (online, 2 December 2018) <https://scroll.in/article/902731/grey-areaassam-seeks-to-merge-nrc-claims-process-with-the-collection-of-biometric-data-foraadhaar>; Silvia Masiero, 'A New Layer of Exclusion? Assam, Aadhaar and the NRC', LSE South Asia (Blog Post, 12 September 2019) <https://blogs.lse.ac.uk/southasia/2019/09/12/anew-layer-of-exclusion-assam-aadhaar-and-the-nrc/>.

109 Vital Statistics of India Based on the Civil Registration System 2018 (Report, Office of the Registrar General, India July 2020) ch 3.17 $<$ http://crsorgi.gov.in/web/uploads/download/crs2018_20072020_approved.pdf $>$. The average level of registration of births as of 2018 was $\overline{89} .3$ per cent, an increase from 81.3 per cent in 2009. 
such as a birth certificate or an identity card - confirming that official registration.

The UN responded to the World Bank's initiatives by the establishment of an inter-agency Legal Identity Expert Group in 2018, which managed to come to an agreed definition of 'legal identity' - in language that underlines both the significance of the concept and the difficulty of tying down what it means in simple terms acceptable to all those interested in the outcome:

Legal identity is defined as the basic characteristics of an individual's identity. e.g. name, sex, place and date of birth conferred through registration and the issuance of a certificate by an authorized civil registration authority following the occurrence of birth. In the absence of birth registration, legal identity may be conferred by a legally-recognized identification authority. This system should be linked to the civil registration system to ensure a holistic approach to legal identity from birth to death. Legal identity is retired by the issuance of a death certificate by the civil registration authority upon registration of death. ${ }^{110}$

The definition, adopted for what is now the UN 'Legal Identity Agenda', highlights the importance of civil registration, in particular birth registration, to the idea of legal identity. Although it omits nationality as part of identity (by contrast to art 8 of the $C R C$ ), it pushes back against an approach based on biometric enrolment of any resident without distinction. If an adult registration process is undertaken, the UN considers it must be linked to the civil register rather than free standing: the Aadhaar approach thus does not 'provide legal identity' under this definition. This is important for those interested in the eradication of statelessness. Although birth registration does not (usually) record nationality or legal status in a country, it does record the information on the basis of which nationality, and many other rights, may be claimed. The 'foundation' it creates for recognition of a person's legal identity is thus stronger (or 'thicker') than an approach based solely on biometric identifiers. Death registration is also important for the recognition of elements of the legal identity, and associated rights, of spouse and children (the legal identity of the deceased in fact lives on in this record). Civil registration generally, including marriage registration, is critical to legal status, especially for rights based on family connections, including nationality: this applies both in countries where nationality is attributed based on birth in the territory, and in those where legally recognised descent from a citizen (or a person resident in the country at a certain date) is the rule.

Operational Guidelines were adopted under the auspices of the Legal Identity Expert Group in May 2020 for UN country teams, 'to support a cohesive approach across the United Nations system'. ${ }^{111}$ This document continues the process of providing greater definitional clarity, and emphasises the importance of setting the SDG Target within a human rights framework, including the protection of migrants, refugees and the forcibly displaced. But although the difficulties created for migrants by lost or destroyed civil status documents are highlighted, ${ }^{112}$ the guidelines do not consider or propose solutions for the difficulties of cross-border

110 United Nations Strategy for Legal Identity for All (Concept Note, United Nations Legal Identity Expert Group 2019) 3 [12].

111 Implementation of the United Nations Legal Identity Agenda: United Nations Country Team Operational Guidelines (Operational Guidelines, United Nations Legal Identity Expert Group, United Nations Development Programme and UNICEF May 2020) 7 $<$ https://unstats.un.org/legal-identity-agenda/documents/UNCT-Guidelines.pdf $>$.

112 ibid 70 . 
recognition of civil status documents, or the information that should be recorded in a birth register in the absence of existing documents.

The UN Statistics Division published a new draft set of guidelines on a legislative framework for CRVS in January 2019, updating the 1998 version and expanding the scope, in order to take SDG Target 16.9 into account and provide a 'holistic and integrated approach to civil registration, vital statistics, and national identity management'. 113 The guidelines mark an important departure, proposing a 'rights-based approach to CRVS legal frameworks', and urging states to ensure that their citizenship laws are 'consistent with ... obligations under international law, including the child's right to a nationality'. ${ }^{114}$ They emphasise the important role of the courts in 'amending or correcting civil registration and identity records and appealing decisions of civil registration and identity management officials'. ${ }^{115}$ There is also a focus on the reduction of statelessness and the minimum legal protections required, and on the registration of births to nationals occurring abroad (with a brief reference to the Apostille Convention). ${ }^{116}$ But there is no guidance on the legal and procedural framework for recognition of foreign civil status documents, or their substitution by the state of residence, nor on the resolution of uncertain nationality of the parents or the child on registration of birth (whether that takes place at the time of birth or later). The recommended information to be registered at birth puts the citizenship of the parents as a low priority item. ${ }^{117}$

Even if these interpretations of state obligations are adopted across the development sector, the impact of the SDG Target on those of undetermined nationality remains uncertain. Central to this uncertainty is the fact that the only action specified by the SDG Target is birth registration, and the only indicator adopted is the coverage of birth registration among those under five years old, with no specification as to the minimum information of the elements of identity to be recorded in the register.

The barriers to birth registration explored above suggest that universal coverage of birth registration will not be possible to achieve unless it is delinked not only from the parents' legal status in the country — creating a wall between civil registration and immigration enforcement — but also from the common requirements to provide documents to prove the nationality of the parent(s) and their legal marriage. But such a decision would have costs, not least in relation to a reduction in statelessness. If these requirements are removed, so that details noted in the birth registry entry could be based on simple declaration by the parents, the nationality of the child remains uncertain - unless the birth is in one of the minority of states (mostly in the Americas) that provide nationality on a jus soli basis without further conditions.

113 Guidelines on the Legislative Framework for Civil Registration, Vital Statistics and Identity Management; Second Draft (Guidelines, United Nations Statistics Division January 2019) [3] ('Draft Guidelines on the Legislative Framework for Civil Registration, Vital Statistics and Identity Management') <https://unstats.un.org/unsd/demographic-social/Standards-andMethods/files/Handbooks/crvs/CRVS_GOLF_Final_Draft-E.pdf $>$.

114 ibid 40, 117-64.

115 ibid 199-204.

116 ibid 162, 304-5.

117 Draft Guidelines on the Legislative Framework for Civil Registration, Vital Statistics and Identity Management (n 113) annex A, 173; the recommendations are taken from Principles and Recommendations for a Vital Statistics System (n 36) 18-19 [66]. The revised framework also drops any hesitancy in the former version relating to the assignment of a single identity number to an individual: see at 61 [275]). 
Thus, even with universal birth registration, many children could be left with undetermined nationality and at risk of statelessness - and would remain so as adults without law and procedural reform to resolve their status. Among those who be stateless without additional protections in law and practice are:

- Children of unknown parents and place of birth;

- Children separated from their parents, including trafficked children or orphans, who hold no copy of a birth certificate or any other documentation;

- Children who cannot acquire nationality from one of their parents, because of gender discrimination in the law (most often, preventing children born out of wedlock from acquiring nationality from their father, or born in wedlock from their mother);

- Children whose rights to nationality depend on the legal recognition of the parents' marriage both in the state where the marriage took place and in the state of the child's birth, and these documents cannot be produced or are not accepted as valid;

- Children of stateless parents;

- Children whose parents' nationality is unknown or undocumented, or whose identity documents are out of date or rejected as fraudulently acquired;

- Children who cannot acquire the nationality of (one of) their parents, because of restrictions on transmission of nationality to those born outside their state(s) of origin;

- Children whose births were registered in the country of birth, but the registration was not transcribed as required, within the relevant timeframes, into the records of the consular or other relevant authorities of the state(s) of origin of the parents;

- Children born through the use of assisted reproductive technologies, including international surrogacy arrangements; and

- Children who cannot acquire a nationality from one of their parents, and who can only acquire the nationality of the state of birth on reaching majority.

In all these cases, ensuring that a child has the right to acquire a nationality will require legal reform and administrative procedures to implement that right in practice. Effective legal protection against statelessness in practice almost always involves providing general legal rights to acquire nationality based on birth and/or residence in a country, given the difficulties of proving statelessness of the child or parent. Efforts to register a child — or adult — with another form of legal status (including the status of stateless person), and a document to match, may be helpful as an interim measure over the short term. But history shows that sometimes such interim measures become permanent, serving to identify as outsiders a group of non-citizens who have no meaningful connection to any other country than the one in which they were born and live.

It seems that there are no short cuts to the legal and political processes required to determine nationality and end statelessness. If an identity other than that of 'resident' is to be registered, both private and public international law must be mobilised to help resolve these uncertainties - ideally at the time of birth, but later if that is not done. A name, birth registration, the recognition of family 
relations and a nationality are rights in international law; states have corresponding obligations.

For private international law, a renewed effort is needed within The Hague Conference to develop stronger guidance on the acceptance and/or reestablishment of civil status documents across borders. Painful as the process would be, it is necessary. The draft UN Guidelines on the Legislative Framework for Civil Registration, Vital Statistics and Identity Management are also an opportunity to provide a more robust legal and procedural framework for the resolution of the status of those whose nationality is not clear. ${ }^{118} \mathrm{~A}$ final or revised version could include a framework for procedures to resolve cases of undetermined nationality, including the late registration of the various different aspects of a person's legal identity, and transcription or independent confirmation and registration of civil status events that originally took place in another country. The World Bank's Principles on Identification for Sustainable Development are also under review. ${ }^{119}$

From the perspective of international human rights law, art 8 of the $C R C$ provides the most useful entry point. In line with the classic tripartite set of obligations, states parties to the $C R C$ should respect, protect, and fulfil the right to identity. There is no existing UN document setting out the content of these obligations in this particular field. However, the outlines are reasonably clear; I propose the following summary. 'Respect' implies that the state will recognise that the identity belongs to the individual and will not interfere with its enjoyment: for example, destroy identity documents or records, or annul or amend them against the person's wishes without a court order, or arbitrarily remove children from their families, broadly defined. 'Protection' requires the state to ensure that records and documents of the key elements of identity (within that state's legal system) are preserved from destruction by others, secured by privacy and data protection laws, and re-established if destroyed, and that private sector registration efforts are properly regulated. The elements of 'fulfilment' would include an obligation to enable comprehensive civil registration (including a right to consular assistance for nationals outside the country and their children born abroad), and to ensure that these registers are easily accessible, including from other countries, and remain so as archives; to adopt a national legal framework that prevents and reduces statelessness; and to establish protection systems to implement these rights. In all cases, basic principles of international human rights law require effective and accessible independent oversight, by courts and other mechanisms, of decisions about the registration of legal identity, including nationality. All of these could be elaborated in greater detail, and prioritised for action according to context.

SDG Target 16.9 is both an opportunity and a threat for stateless persons and those at risk of statelessness. The opportunity is the belated emphasis on the importance of official recognition and registration as a means for an individual to assert rights as a member of society. The threat is the danger that short cuts and interim solutions, a utilitarian commitment to the majority or to the priorities of the state rather than the individual, mean those of 'doubtful' status are — despite the SDG commitment - left behind.

118 See Draft Guidelines on the Legislative Framework for Civil Registration, Vital Statistics and Identity Management (n 113).

119 See Principles on Identification for Sustainable Development (n 105). 